\title{
MARKET MULTIPLES ADJUSTMENTS FOR DIFFERENCES IN RISK PROFILE - AN AIRLINE COMPANY EXAMPLE
}

\author{
Nina Milenković1 \\ ${ }^{1}$ KPMG LLC Belgrade, Kraljice Natalije 11, 11000 Belgrade, Serbia
}

Received 26 November 2014; accepted 19 January 2015

\begin{abstract}
Companies whose data can be found in databases usually are not comparable enough to the valuation subject to assure direct use of their multiples (i.e. to assure reliability of valuation resulting from direct use of their multiples). Key differences usually relate to size, but also to other characteristics (financial performance, territory, business profile, expected growth, etc.), all of impact on specific risks. This paper shows how to adjust multiples for risk profile differences to achieve satisfactory level of comparability and consequent reliability of valuation on the example of airline company.
\end{abstract}

Keywords: valuation, market multiples, capitalization rate, WACC, specific risks.

\section{Introduction}

The market approach is one of the traditional approaches to valuation. It is based on the principle of substitution and the premise that a rational investor will not pay for an asset/ company a higher amount than he would pay on the market for the purchase of an asset/company with similar characteristics and utility. As a result, application of the market approach usually includes the use of market multiples calculated for comparable companies that are listed on active stock markets or that have recently been sold/ purchased. Multiples are based on data about market value of equity and debt, and information from financial statements of selected comparable companies. The sources of data about comparable companies are usually specialized databases (Bloomberg, Capital IQ, Amadeus, Infinancials, Damodaran, etc.). These databases contain comprehensive information about a large number of companies, but only for those companies that exceed threshold values in terms of size (thresholds vary, but they mainly relate to annual turnover in excess of 50 million USD).

When the valuation subject is a large company, a multinational or one that operates on a developed market, most often the multiples can be used directly. However, when undeveloped or emerging markets are involved, in which the business environment differs significantly, and valuation subject companies are often as much as one hundred times smaller, direct use of multiples would produce distorted results, mostly with significant overestimation of their value. For this reason market multiples need to be adjusted by a factor or factors which will take into account key differences between a selected sample and the valuation subject.

${ }^{1}$ Corresponding author: nmilenkovic@kpmg.com 
These factors are very often determined subjectively, based on qualitative analysis of risk profile and the appraiser's experience. However, it is precisely the subjectivity of such an approach that represents its greatest weakness, because the result is directly dependent on the level of adjustment, and is perforce subject to error and even to manipulation. That is why it is much better if the adjustment factor is determined using a quantitative method. It is desirable, therefore, for factors that are taken into account for the adjustment to be consistent with factors that were used in determining the discount rate as part of the income approach.

The paper considers the most common quantitative methods and techniques for adjusting multiples. Special attention is given to methods that include individual or combined consideration of risk factors which is consistently or directly linked to the discount rate.

\section{Adjustments for Market Differences}

The commonest reason that appraisers mention for correcting multiples are market differences, namely the fact that doing business in an emerging market generally differs significantly from doing business in developed markets. Isolated adjusting of multiples for differences in market risks can be carried out in several ways:

- through yields on government bonds,

- through relative ratios between multiples,

- regression analysis.

Adjustment through yields on government bonds of countries in which comparable companies are located and in which the valuation subject operates represents a simple modification of country risk which is used in determining the discount rate and is calculated as follows:

$M_{a d j}=\frac{Y T M_{B}}{Y T M_{C}} \cdot M_{o r}$

where:

$\mathrm{M}_{\mathrm{adj}}$ - adjusted multiple,

$\mathrm{M}_{\text {or }}$ - original multiple,

$\mathrm{YTM}_{\mathrm{B}}$ - yield to maturity of government bonds of the benchmark country,

$\mathrm{YTM}_{\mathrm{C}}$ - yield to maturity of government bonds of the country of the valuation subject.

The prerequisite for use of this method is for comparable bonds to have identical maturities (measured in days). If this is not the case, the yield to maturity needs to be recalculated in order for currency and maturity to be the same (Ivashkovskaya and Kuznetsov (2007) recalculate maturities using regression).

Moreover, attention should be given to the currency in which the bonds are denominated: it is not necessary for the currencies to be the same, but this should be kept in mind in interpreting the results (whether the adjustment also contains currency risk or not).

The advantage of this method is that it is fairly straightforward and can be applied using any type of multiple, irrespective of whether it is based on earnings level or assets (see Appendix 1 for more on types and definitions of multiples). The main drawback is that it completely ignores other specific risks of companies in emerging markets.

Relative ratios between multiples are conceptually based on a comparison of 
average multiples for the entire economy of two countries in a specific time period. After this, such a general ratio is applied to specific multiples calculated from the sample of comparable companies.

$M_{a d j}=\frac{\text { median } M_{C}}{\text { median } M_{B}} \cdot M_{o r}$

where all symbols carry the same meaning as in Eq. (1).

This method is slightly better than the previous one, because the average multiple for the entire country also includes other risks, beside the basic country risk. It can also be applied to all types of multiples. However, in order for it to be applicable, it is necessary for the country where the valuation subject is located to have an active securities market, for accounting standards to be comparable and for a sufficiently large number of companies to be included in order for the multiple to be considered representative. It is precisely for this reason that this method would not provide sufficiently reliable results for companies in Serbia.

Adjustments using regression analysis are based on the idea that the value of a multiple depends on the fundamental variable on which it is based and on the dummy variable which represents the country/market where business is conducted. Prerequisites for the use of this method are similar as with the relative ratio of multiples. Depending on data availability, this method frequently provides excellent results. Also, it can be expended by adding variables (actual or dummy) that relate to other risk factors such as commercial activity, size, growth, etc. (for more details see Ivashkovskaya and Kuznetsov, 2007; Welc, 2011; Acosta, 2011).

\section{Adjustments for Differences in other Risk Factors}

As already mentioned, differences in market conditions of doing business are often not the only significant differences between companies whose data is available in databases and publications and the valuation subject company. That is why an unavoidable step in using market multiples includes a detailed analysis of individual risk factors of companies in the sample and the valuation subject company, based on which it is concluded whether a certain factor has a dominant role or whether differences are evenly distributed (sometimes they also relate to factors that cannot be directly quantified). Depending on the results of the analysis, adjustment methods are used for individual factors or for the risk profile as a whole.

\subsection{Adjustments for Individual Risk Factors}

The most frequently identified individual risk factors that are dominantly incomparable are expected profit growth and company size. Namely, it is common for larger companies and companies with faster expected growth to have higher multiples than those that are smaller and that have lower expectations in the future.

Based on the relationship between the most general multiple $\mathrm{P} / \mathrm{E}$, risk rate and longterm growth rate (for further details see Appendix 2) and the fact that both factors are additive in the denominator of the ratio (10), a formula has been derived for adjustment of multiples for individual risk factors which is as follows for a general case: 


$$
M_{\text {adj }}=\frac{1}{\frac{1}{M_{\text {or }}}+\text { adjustment factor }}
$$

where symbols carry the same meaning as in Eq. (1).

The adjustment factor in this method is usually the difference in the selected risk factor measure between the benchmark and the valuation subject company (when factor is of the same direction as the multiple value).

The formula for adjusting the multiple for the difference in expected profit growth is as follows:

$M_{a d j}=\frac{1}{\frac{1}{M_{o r}}+\left(g_{B}-g_{s}\right)}$

where $g$ stands for the blended long-term growth rate, the index $s$ for the specific valuation subject company, while other symbols and indices remain as before.

In order for this method to be applied, it is necessary to calculate the blended longterm growth rate. Namely, the growth rate which is implicitly contained in the discount rate represents a steady growth rate for an indefinite period into the future, which for the majority of commercial activities and companies over a sufficiently long period converges with the long-term GDP growth rate. Differences in growth, hence, relate to a period of the next 3-5 years, which is most frequently the subject of estimates and projections made by company management and financial analysts. The blended rate is calculated by firstly calculating the projection of profit levels, based on the initial value of profit and projected growth rates for different periods, after which the present value of future profits is calculated using the appropriate discount rate. By calculating the ratio between this value and initial profit levels one gets the indirectly assumed rate of capitalization, from which (using the same discount rate) one gets the blended growth rate (more detailed explanation provided by Hitchner (2003), with one calculation method provided by Tallis (2012)).

In order for the adjustment result to be valid, care must be taken of the consistency between the denominator of the multiple and the growth rate, as well as between the numerator and the discount rate. Moreover, such adjustment only makes sense for earnings based multiples, and not for asset based multiples.

For adjusting the multiple for the difference in company size, the formula is as follows:

$M_{a d j}=\frac{1}{\frac{1}{M_{o r}}+\left(S R P_{S}-S R P_{B}\right)}$

where SRP stands for specific risk premium for company size, while other symbols and indices remain as before.

The effect of the risk premium on the multiple has an opposite direction with respect to company size, such that the benchmark and the valuation subject company have changed places in the adjustment multiple. It is assumed that the benchmark companies are larger than the subject company, i.e. that the subject company has higher size risk premium.

The risk premium for company size is taken by the majority of appraisers from statistics publications published by Ibbotson Associates. Unfortunately, this data relates to American or global companies which, even being in the tenth decile (the smallest 
one), are frequently dramatically larger than Serbian companies; in other words, risk premiums for size within the tenth decile are not sufficiently differentiated. A possible solution has been announced in Dragon (2010): Chinese statistics for small companies whose shares are regularly traded on securities markets. Another disadvantage of isolated size-based adjustment is presented in Grabowski (2014), based on Peek (2014). Study shows that the relationship between firm size and returns could not be seen as linear and straightforward, because it varies across regions.

The adjustments described in Eqs. (4) and (5) relate to the $\mathrm{P} / \mathrm{E}$ multiple. In order for it to be applicable to other multiples, additional adjustments need to be made, which for a general case can be presented as:

$$
M_{a d j}=\frac{1}{\frac{1}{M_{o r}}+\alpha \cdot \epsilon \cdot \text { adjustment factor }}
$$

where:

$\alpha$-modifying coefficient for variations in the multiple denominator,

$\varepsilon$ - modifying coefficient for variations in the multiple numerator.

The equivalent for the $\mathrm{P} / \mathrm{E}$ multiple applicable for invested capital is MVIC/EBIAT (Earnings Before Interest After Taxes). Given that the size risk premium is part of the cost of equity, it will affect WACC only to the extent that equity participates in the invested capital (see Appendix 3). Hence, in order for Eq. (5) to be applicable to the MVIC multiple, the adjustment factor must be multiplied by the modifying coefficient $\varepsilon$, which represents the share of equity in invested capital.

Furthermore, if the use of a multiple which is based on another earnings measure is intended (revenue, EBITDA, EBIT), modifying coefficient $\alpha$, representing the ratio between net income and the other earnings measure, must be applied.

Finally, it should be noted that country risk can also be used as an adjustment factor.

All of the above adjustments can be combined, but generating a single formula would be unnecessarily complicated - it is simpler to carry out several successive steps (Mercer, 2013). The risk of such procedure is a drastic decrease in the multiple.

\subsection{Adjustments for Combined Risk Factors through the Discount Rate}

When analysis does not point to the dominant effect of any particular risk factor or there are several significant factors, so successive adjustments would reduce the multiple to an illogically small value or, on the other hand, there are significant specific risks that are not typical for companies in developed markets, it is the best solution to combine all factors through the discount rate, as follows:

$M_{a d j}=\frac{D R_{B}}{D R_{S}} \cdot M_{o r}$

where DR stands for the discount rate, while other symbols and indices remain as before.

The "adjusting" discount rate for comparable companies is calculated in usual way (see Appendix 3). In doing so, the risk free rate, country risk and risk premium for size are taken from actual data for the country and the company, while for other components average values (best to use median values) of the entire sample of comparable companies are taken. 
Since the ratio of rates is a relative (unnamed) number, this method can be applied to any multiple, with one (methodo)logical limitation: the multiple numerator and discount rates used must be consistent. In other words, there is no sense in adjusting equity multiples by ratio of two WACCs.

Alternatively, the discount rates of the valuation subject company and comparable companies can be used in Eq. (5) instead of SRP, where as in the previous method, care should be taken of the consistency between the multiple and the discount rate. Of course, introduction of coefficient $\alpha$ is mandatory, representing the ratio between net profit and cash flow. Besides conjoint capturing of more risks, the advantage of this method lies in its simplicity (data has already been collected for determining the discount rate for the income approach), as well as in its direct link to the income approach. Thus it is highly unlikely for results to differ to such an extent that the market approach cannot be applied. Should this nevertheless happens, it is necessary to reconsider the selection of companies, assumptions and calculations in the income approach, and in the event of a significant difference in expected growth, it is sometimes necessary to apply an additional adjustment for this factor.

\section{An Illustrative Example: Airline Company}

A good example of combined risk factors are companies from airline industry. In brief, industry economic profile is characterized by low profits, high indebtedness and uneven distribution of returns and risk across the value chain (a thorough analysis of air transport value chain is presented in Pearce (2013)). Regarding investment attractiveness, air industry rewards debt providers, both creditors and lessors, as loans are expensive and often secured by very mobile and saleable asset, i.e. aircraft. On the other hand, reward for equity owners is permanently below the opportunity cost, measured by WACC. According to IATA (2014), although trends are improving during the last two years and expected ROIC (return on invested capital) for 2014 is $5.4 \%$, it is "more than 2 percentage points lower than it should be in an industry that is highly competitive" (IATA, 2014).

However, not all companies fit in this profile. Some of them are in deleveraging process, while others restructure its debt increasing use of leasing (both operating and financial); they operate in different countries, with different degree of government regulations; different business models are in place as well as different stages in lifecycle. A lot of those differences are not clearly visible or assessable from information available in databases. Multiple adjustments procedure is illustrated on the example of regional airline company; as it is real company, for confidentiality reasons here it is named Eastern Air. Basic company financials are shown in Table 1.

\section{Table 1}

Basic Financials for Eastern Air for the Last Fiscal Year

\begin{tabular}{|l|r|}
\hline Eastern Air & 000 USD \\
\hline Book Value of Equity & 74.90 \\
\hline Total Debt (Leasing) & $2,801.90$ \\
\hline Invested Capital(D+E) & $2,876.80$ \\
\hline Cash & 1.00 \\
\hline Enterprise Value & $2,875.80$ \\
\hline Debt to Invested Capital ratio (D/D+E) & $97.40 \%$ \\
\hline Debt to Equity ratio (D/E) & $3740.86 \%$ \\
\hline Revenues & $6,489.90$ \\
\hline EBITDA & 659.60 \\
\hline EBIT & 50.02 \\
\hline Net Income & $(16.22)$ \\
\hline
\end{tabular}

Source: Financial statements for the last fiscal year 
The company operates mostly in Europe, having a few intercontinental lines as well. The majority owner is state, and minority shareholders are also mostly government institutions. Shares are not quoted on the local stock exchange.

The company is highly indebted and whole debt is in form of leasing. Bad management combined with high interest expenses lead company to loss making zone, so the book value of equity is very low.
Having relatively new fleet, well operating regional lines and access to some interesting airports, the company could be a desirable acquisition target. For the purpose of illustration it is assumed that potential acquirer's consultant is asked to conduct a quick indicative valuation. Market multiples are often the first choice. The consultant formed peer group, using data from Damodaran database (available from Internet: <www.damodaran.com >, free of charge). Multiples are shown in Table 2.

Table 2

Market Multiples

\begin{tabular}{|l|l|r|r|r|r|r|r|r|}
\hline & & & \multicolumn{3}{|c|}{ Market Multiples - Unadjusted } \\
\cline { 5 - 9 } Company Name & Country & $\begin{array}{r}\text { Market } \\
\text { cap }\end{array}$ & $\begin{array}{r}\text { Market } \\
\text { D/D+E }\end{array}$ & PE & PS & $\begin{array}{r}\text { EV/ } \\
\text { EBIT }\end{array}$ & $\begin{array}{r}\text { EV/ } \\
\text { EBITDA }\end{array}$ & $\begin{array}{r}\text { EV/ } \\
\text { Sales }\end{array}$ \\
\hline Finnair Oyj & Finland & 489.2 & $73.44 \%$ & 16.31 & 0.15 & 11.23 & 8.95 & 0.51 \\
\hline Air France-KLM SA & France & $3,092.6$ & $87.67 \%$ & NA & 0.09 & 35.01 & 12.56 & 0.59 \\
\hline Aegean Airlines S.A. & Greece & 575.3 & $36.65 \%$ & 7.41 & 0.66 & 3.99 & 270.17 & 0.68 \\
\hline Icelandair Group hf. & Iceland & 788.2 & $29.55 \%$ & 13.76 & 0.88 & 8.17 & 8.46 & 1.01 \\
\hline Aer Lingus Group plc & Ireland & 939.3 & $49.42 \%$ & 22.31 & 0.51 & 16.51 & 8.10 & 0.78 \\
\hline Norwegian Air Shuttle ASA & Norway & $1,090.1$ & $74.05 \%$ & 12.17 & 0.47 & NA & 20.17 & 1.66 \\
\hline Aeroflot - Russian Airlines & Russia & $2,688.5$ & $67.13 \%$ & 6.25 & 0.33 & 9.04 & 11.37 & 0.91 \\
\hline Transaero Airlines & Russia & 725.8 & $77.41 \%$ & 21.86 & 0.23 & 13.90 & 12.23 & 0.99 \\
\hline UTair Aviation & Russia & 393.3 & $83.85 \%$ & 28.50 & 0.15 & 5.41 & 8.27 & 0.92 \\
\hline SAS AB & Sweden & 845.5 & $67.79 \%$ & 30.75 & 0.13 & 3.51 & 3.64 & 0.29 \\
\hline Türk Hava Yollari A.O. & Turkey & $4,140.1$ & $59.08 \%$ & 7.72 & 0.50 & 9.50 & 7.44 & 1.11 \\
\hline $\begin{array}{l}\text { Pegasus Hava Tasimaciligi } \\
\text { Anonim Sirket }\end{array}$ & Turkey & $1,729.5$ & $29.97 \%$ & 17.49 & 1.61 & 8.93 & 12.03 & 1.85 \\
\hline Median & & & $\mathbf{6 7 . 4 6 \%}$ & $\mathbf{1 6 . 3 1}$ & $\mathbf{0 . 4 0}$ & $\mathbf{9 . 0 4}$ & $\mathbf{1 0 . 1 6}$ & $\mathbf{0 . 9 2}$ \\
\hline
\end{tabular}

Comparing Eastern Air's profile with peer group, it is obvious that all selected companies are much bigger, are settled in more developed countries and are less indebted. Moreover, there is no information about assets/fleet values, but comparing EBITDA and EBIT multiples it seems that $i$ ) depreciation share in revenue is lower in comparable companies and ii) some of the companies have non-cash nonoperating revenues. Finally, although there are data in database about debt structure and amount of leasing, there are no information on type and terms of leasing. All those differences and potential differences make multiple adjustments necessary.

In calculation of "adjusting" WACC for comparable companies and Eastern Air the build-up method is selected and the following components are used (Table 3): 
- $\quad$ risk-free rate: return on US government bonds as at valuation date,

- market risk premium: consultant estimation, based on different research studies,

- country risk premium: assessed for each country, based on credit rating,

- size risk premium: from Ibbotson Associates Yearbook, in line with market capitalization,

Table 3

"Adjusting" WACC Calculation

\begin{tabular}{|c|c|c|c|c|c|c|c|c|}
\hline Company Name & $\begin{array}{r}\text { Risk- } \\
\text { free }\end{array}$ & ERP & CRP & SRP & $\begin{array}{l}\text { Cost of } \\
\text { Equity }\end{array}$ & $\begin{array}{r}\text { Cost of } \\
\text { Debt }\end{array}$ & $\mathbf{E} / \mathbf{D}+\mathbf{E}$ & $\begin{array}{r}\text { Adj. } \\
\text { WACC }\end{array}$ \\
\hline Finnair Oyj & $4.00 \%$ & $5.50 \%$ & $0.0 \%$ & $2.65 \%$ & $12.15 \%$ & $4.75 \%$ & $32.54 \%$ & $7.16 \%$ \\
\hline Air France-KLM SA & $4.00 \%$ & $5.50 \%$ & $0.6 \%$ & $1.20 \%$ & $11.30 \%$ & $4.75 \%$ & $32.54 \%$ & $6.88 \%$ \\
\hline Aegean Airlines S.A. & $4.00 \%$ & $5.50 \%$ & $8.5 \%$ & $2.65 \%$ & $20.65 \%$ & $4.75 \%$ & $32.54 \%$ & $9.92 \%$ \\
\hline Icelandair Group hf. & $4.00 \%$ & $5.50 \%$ & $2.4 \%$ & $1.88 \%$ & $13.78 \%$ & $4.75 \%$ & $32.54 \%$ & $7.69 \%$ \\
\hline Aer Lingus Group plc & $4.00 \%$ & $5.50 \%$ & $2.4 \%$ & $1.88 \%$ & $13.78 \%$ & $4.75 \%$ & $32.54 \%$ & $7.69 \%$ \\
\hline Norwegian Air Shuttle ASA & $4.00 \%$ & $5.50 \%$ & $0.0 \%$ & $1.88 \%$ & $11.38 \%$ & $4.75 \%$ & $32.54 \%$ & $6.91 \%$ \\
\hline Aeroflot - Russian Airlines & $4.00 \%$ & $5.50 \%$ & $1.6 \%$ & $1.20 \%$ & $12.30 \%$ & $4.75 \%$ & $32.54 \%$ & $7.21 \%$ \\
\hline Transaero Airlines & $4.00 \%$ & $5.50 \%$ & $1.6 \%$ & $2.65 \%$ & $13.75 \%$ & $4.75 \%$ & $32.54 \%$ & $7.68 \%$ \\
\hline UTair Aviation & $4.00 \%$ & $5.50 \%$ & $1.6 \%$ & $2.94 \%$ & $14.04 \%$ & $4.75 \%$ & $32.54 \%$ & $7.77 \%$ \\
\hline SAS AB & $4.00 \%$ & $5.50 \%$ & $0.0 \%$ & $1.88 \%$ & $11.38 \%$ & $4.75 \%$ & $32.54 \%$ & $6.91 \%$ \\
\hline Türk Hava Yollari A.O. & $4.00 \%$ & $5.50 \%$ & $2.5 \%$ & $1.01 \%$ & $13.01 \%$ & $4.75 \%$ & $32.54 \%$ & $7.44 \%$ \\
\hline $\begin{array}{l}\text { Pegasus Hava Tasimaciligi } \\
\text { Anonim Sirket }\end{array}$ & $4.00 \%$ & $5.50 \%$ & $2.5 \%$ & $1.82 \%$ & $13.82 \%$ & $4.75 \%$ & $32.54 \%$ & $7.70 \%$ \\
\hline Eastern Air & $4.00 \%$ & $\mathbf{5 . 5 0} \%$ & $4.00 \%$ & $12.06 \%$ & $25.56 \%$ & $4.75 \%$ & $32.54 \%$ & $11.52 \%$ \\
\hline
\end{tabular}

In final step, consultant calculated two adjusting factors, one for equity multiples (ratio between two costs of equity) and for enterprise value multiples (ratio between two WACCs) and applied them to market
- cost of debt (after-tax): median of comparable companies' data,

- capital structure: median of comparable companies' data.

It is important to mention that calculated "adjusting" WACC is not the actual WACC for those companies and that specific company risk could also be added. 
Table 4

Adjusted Multiples and Valuation Analysis

\begin{tabular}{|c|c|c|c|c|c|c|c|}
\hline \multirow[b]{2}{*}{ Company Name } & \multirow[b]{2}{*}{$\begin{array}{l}\text { Adj.factor } \\
\text { for equity } \\
\text { multiples }\end{array}$} & \multirow[b]{2}{*}{$\begin{array}{r}\text { Adj.factor } \\
\text { for EV } \\
\text { multiples }\end{array}$} & \multicolumn{5}{|c|}{ Market Multiples - Adjusted } \\
\hline & & & $\mathbf{P E}$ & PS & $\begin{array}{r}\text { EV/ } \\
\text { EBIT }\end{array}$ & $\begin{array}{r}\text { EV/ } \\
\text { EBITDA }\end{array}$ & $\begin{array}{l}\text { EV/ } \\
\text { Sales }\end{array}$ \\
\hline Finnair Oyj & 0.48 & 0.62 & 7.75 & 0.07 & 6.98 & 5.56 & 0.32 \\
\hline Air France-KLM SA & 0.44 & 0.60 & NA & 0.04 & 20.91 & 7.50 & 0.35 \\
\hline Aegean Airlines S.A. & 0.81 & 0.86 & 5.99 & 0.53 & 3.44 & 232.71 & 0.59 \\
\hline Icelandair Group hf. & 0.54 & 0.67 & 7.42 & 0.47 & 5.45 & 5.65 & 0.67 \\
\hline Aer Lingus Group plc & 0.54 & 0.67 & 12.03 & 0.27 & 11.02 & 5.41 & 0.52 \\
\hline $\begin{array}{l}\text { Norwegian Air Shuttle } \\
\text { ASA }\end{array}$ & 0.45 & 0.60 & 5.42 & 0.21 & NA & 12.09 & 1.00 \\
\hline $\begin{array}{l}\text { Aeroflot - Russian } \\
\text { Airlines }\end{array}$ & 0.48 & 0.63 & 3.01 & 0.16 & 5.65 & 7.11 & 0.57 \\
\hline Transaero Airlines & 0.54 & 0.67 & 11.76 & 0.12 & 9.26 & 8.15 & 0.66 \\
\hline UTair Aviation & 0.55 & 0.67 & 15.65 & 0.08 & 3.65 & 5.58 & 0.62 \\
\hline SAS AB & 0.45 & 0.60 & 13.69 & 0.06 & 2.10 & 2.18 & 0.17 \\
\hline Türk Hava Yollari A.O. & 0.51 & 0.65 & 3.93 & 0.25 & 6.13 & 4.80 & 0.72 \\
\hline $\begin{array}{l}\text { Pegasus Hava } \\
\text { Tasimaciligi Anonim } \\
\text { Sirket }\end{array}$ & 0.54 & 0.67 & 9.46 & 0.87 & 5.97 & 8.04 & 1.24 \\
\hline Median & & & 7.75 & 0.18 & 5.97 & 6.38 & 0.60 \\
\hline Multiple base & & & Earnings & Sales & EBIT & EBITDA & Sales \\
\hline Eastern Air actuals & & & $(16.2)$ & $6,489.9$ & 50.0 & 659.6 & $6,489.9$ \\
\hline Enterprise value & & & & & 298.6 & $4,207.4$ & $3,914.6$ \\
\hline Interest bearing debt & & & & & $(2,801.9)$ & $(2,801.9)$ & $(2,801.9)$ \\
\hline Cash & & & & & 1.0 & 1.0 & 1.0 \\
\hline Preliminary value & & & $(125.8)$ & $1,194.3$ & $(2,502.3)$ & $1,406.5$ & $1,113.7$ \\
\hline $\begin{array}{l}\text { Appraised value } \\
\text { of equity, non- } \\
\text { controlling, } \\
\text { marketable (rounded) }\end{array}$ & & & $\mathbf{0}$ & $1,200.0$ & $\mathbf{0}$ & $1,400.0$ & $1,100.0$ \\
\hline
\end{tabular}

As earnings and EBIT multiple give negative values, resulting value of equity would be zero, but due to negative earnings and very low EBIT, those two multiples should have been excluded from the analysis at the beginning (left here for illustration). In real world valuation, the result would be either value range from 1.1 to 1.4 mil.USD or single point value - the most probably, value based on EBITDA multiple, i.e. 1.4 mil.USD (final value reconciliation and discussion is beyond the scope of this paper). 


\section{Conclusion}

Insufficient comparability between small companies in emerging markets and companies for which data can be found in specialized databases and publications frequently leads to unreliable valuation results generated using the market approach, so its application is often being limited to only illustrative/control purposes.

This paper presents the main sources of differences and the most frequently used methods for adjusting market multiples. A detailed analysis of risk profile is very useful in the selection of the method and risk factors for adjustment, but the ultimate choice always rests with the appraiser.

The author of this paper holds that even in the event when a single risk factor is a dominant source of risk, adjustments through the discount rate are the best choice as they take into account those risks which are not directly quantifiable (key person, lack of corporate governance, organizational structure, etc.), but that are frequently present in small companies on the Serbian market and on similar markets.

\section{Appendix 1: The Most Common Market Multiples}

Market multiples are ratios between selected level of market value (equity, firm value, enterprise value, other variations) and appropriate level of income stream (revenue, EBIT, EBITDA, net income, cash flow, etc.) or assets (book value of equity, tangible book value etc.). In some industries, it is useful to develop multiples based on some natural indicator (e.g. capacity in GWh for power plants, number of rooms for hotels etc.).
In multiple selection and calculation the logic and consistency are of critical importance, so only mutually consistent items should form ratios (for example, it does not make sense to form ratio "invested capital to earnings" due to inconsistency in debt treatment).

The most common equity multiples are:

- P/E (Price to Earnings) - Market capitalization to net income,

- P/S (Price to Sales) - Market capitalization to net sales or operating revenue,

- $\quad$ P/BV (Price to Book Value) - Market capitalization to book value of equity.

The most common invested capital multiples (invested capital equals equity plus interest bearing debt; often is called firm value; when cash is subtracted, it is enterprise value):

- $\quad$ MVIC/EBIT (Market Value of Invested Capital to EBIT) - Market value of invested capital (market capitalization plus market value of interest bearing debt) to earnings before interest and taxes,

- MVIC/EBITDA (Market Value of Invested Capital to EBITDA) - Market value of invested capital to earnings before depreciation, amortization, interest and taxes,

- $\quad$ MVIC/S (Market Value of Invested Capital to Sales) - Market value of invested capital to revenue.

Market multiples could relate to different time intervals: last fiscal year, last twelve months, next twelve months, etc. To be precise, time intervals relate to denominator, while value is nominator should be as at the last day of that interval, i.e. valuation date. 
Application of multiples is very simple calculated market multiple multiplies with amount of appropriate earnings stream or assets of valuation subject which must be from same time interval as multiple. Any inconsistency leads to significant results distortion.

\section{Appendix 2: Relationship between Multiples, Capitalization Rate and Discount Rate}

When it is expected that some level of earnings would grow at the constant sustainable rate in indefinite future period it is possible to transform its annual amount into value of flow's generator (source) using appropriate capitalization rate. In case of net income, capitalization would result in value of equity.

$V_{s}=\frac{E_{S}}{C R_{E}}$

where:

$\mathrm{V}_{\mathrm{s}}$ - value of subject company's equity,

$\mathrm{E}_{\mathrm{s}}$ - earnings (net income) of subject company,

$\mathrm{CR}_{\mathrm{E}}$ - capitalization rate of earnings.

On the other hand, equity value could be calculated applying market $\mathrm{P} / \mathrm{E}$ multiple to the subjects company's earnings:

$V_{s}=\frac{P}{E} \cdot E_{S}$

It follows from the above that $\mathrm{P} / \mathrm{E}$ is in fact reciprocal value of capitalization rate applicable to earnings. As capitalization rate is equal to discount rate reduced for implied growth, the following identities hold:

$\frac{P}{E}=\frac{1}{C R_{E}}=\frac{1}{D R_{E}-g_{E}}$ where:

$\mathrm{DR}_{\mathrm{E}}$ - discount rate applicable to net income, $\mathrm{g}_{\mathrm{E}}$ - long term growth rate of net income (more precisely, earnings per share) in indefinite future period.

Other fundamentals could be analyzed in similar way. For more details see Fernandez (2013).

\section{Appendix 3: WACC Definition and Components}

Discount rate is the rate which converts company's cash flows into the value of capital. Depending of the sources of cash flow, discount rate could be related either to equity or to the invested capital (also some of its variations, firm value or enterprise value). In more general case, when cash flows before debt service (formerly called debtfree cash flows) are subject of discounting, the appropriate discount rate is Weighted Average Cost of Capital (WACC), usually presented as:

$W A C C=r_{E} \cdot \frac{E}{V}+r_{D} \cdot(1-t) \cdot \frac{D}{V}=$
$=\left(r_{f}+\beta \cdot E R P+C R P+S C R\right) \cdot \frac{E}{V}+r_{D} \cdot(1-t) \cdot \frac{D}{V}$

where:

$r_{E}-$ cost of equity, i.e. required rate of return, $r_{f}$ - risk-free rate, i.e. rate of return of the least risky investments (usually government bonds),

$\beta$ - beta coefficient, measure of systematic risk,

ERP - market risk premium for investing in equities, the difference between return on market portfolio of equities and the riskfree rate, CRP - country risk premium, SCR - specific company risk, $r_{D}$ - cost of debt, pre-tax, 
E - equity,

$\mathrm{D}$ - debt (usually interest-bearing),

$\mathrm{V}$ - invested capital (E+D),

$\mathrm{E} / \mathrm{V}$ - equity share in invested capital,

$\mathrm{D} / \mathrm{V}$ - debt share in invested capital, $\mathrm{t}$ - tax rate.

The cost of equity in the above relation is determined by modified CAPM method. When beta is omitted, relation becomes "build-up" method, sometimes easier to obtain data for. However, specific company risk assessed within build-up method should include industry risk and possible other risk factors usually captured by beta.

As already mentioned, discount rate is usually applied to cash flow. When other earnings measure is to be discounted (as in Appendix 2), appropriate adjustments are required.

\section{References}

Acosta, C.C.2011. REVAAM Model Applied to Multiple Valuation Comparison Among Different World Regions, Business Intelligence Journal, 4(2): 273-292.

Dragon, R.J. 2010. Adjusting Valuation Multiples and the China Price (Part 1), blog "RJ on BV" on AccountingWEB. Available from Internet: <http:// www.accountingweb.com/blogs/dragon 4/rj-bv/ adjusting-valuation-multiples-and-china-price-part-1>.

Fernandez, P. 2013. Valuation and Common Sense, 2nd edition, IESE Business School, University of Navarra, CH27-11 to CH27-18. Available from Internet: <http:// ssrn.com/abstract $=2212373>$.

Grabowski, R.J. 2014. Estimating Discount Rate in Global and Local Financial Environment, seminar, Ljubljana, 7 October 2014. 86-97.
Hitchner, J.R. 2003. Financial Valuation-Application and Models, John Wiley \& Sons.

IATA 2014. Economic Performance of the Airline Industry (2014 mid-year report). Available from Internet: <www.iata.org/economics>.

Ivashkovskaya, I.; Kuznetsov, I. 2007. An Empirical Study of Country Risk Adjustments to Market Multiples Valuation in Emerging Markets: the Case for Russia, $\exists \wedge$ ектронныйжурналКорпоративныеФинансы, 3: 26-52.

Mercer, Z.C. 2013. Fundamental Adjustments to Market Capitalization Rates, reprinted from Mercer Capital's Value Metters $^{\text {TM }}$ 2004-11. Available from Internet: <http:// mercercapital.com $>$.

Pearce, B. 2013. Profitability and the Air Transport Value Chain, IATA Economics Briefing $\mathrm{N}^{\circ} 10$. Available from Internet: <www.iata.org/economics>.

Peek, E. 2014. A Study of Differences in Returns between Large and Small Companies in Europe, Rotterdam School of Management, Erasmus University. Research Commissioned by Duff \& Phelps LLC. Available from Internet: <http://papers.ssrn.com/sol3/papers. cfm?abstract_id=2499205>.

Standard \& Poor's 2008. Key Credit Factors: Business and Financial Risks in the Airline Industry, Global Credit Portal. Available from Internet: <www. standardandpoors.com/ratingsdirect $>$.

Tallis, H. 2012. Adjust valuation multiple for growth, blog "Quantitative Corporate Finance”. Available from Internet: <http://www.quantcorpfin.com/cookbook/ quantitative-analysis/adjust-valuation-multiple-forgrowth/>.

Welc, J. 2011. Do fundamentally-adjusted valuation multiples improve valuation accuracy? The case of Polish stock market, Accounting \& Taxation, 3(1): 57-70. 